\title{
Focus
}

\section{De erfenis van het westerse christendom}

\author{
J. Hoek
}

N.a.v. Tom Holland, Dominion. The making of the Western Mind, Little, Brown, Londen 2019, 594 p., £ 14,99 (ISBN 9781408706961). Nederlandse vertaling: Heerschappij. Hoe het christendom het Westen vormde, Athenaeum, Amsterdam 2020, 640 p., € 29,99 (ISBN 9789025305673 ).

\section{Zwemmen in christelijk water}

De Britse historicus en veelgelezen auteur Tom Holland (1968) biedt in zijn nieuwe boek Dominion geen omvattende geschiedenis van het christendom. Hij schreef een breed en diepgaand essay, waarin naast kruispunten en hoofdlijnen met name veel interessante anekdotes uit de historie van het westerse of Latijnse christendom naar voren komen. Deze 'populariserende genealogie van ideeën' (Stefan Paas) is geschreven vanuit de overtuiging dat het christelijk geloof, en breder het christendom, tot op de dag van vandaag in veel opzichten zijn stempel zet op de westerse cultuur en zelfs op mondiale ontwikkelingen. Veel van wat moderne mensen beschouwen als fundamentele menselijke waarden en indiscutabele overtuigingen gaat terug op christelijke wortels, bijvoorbeeld op een bijbelwoord als Galaten 3:28: 'Daarbij is het niet van belang dat men Jood is of Griek; daarbij is het niet van belang dat men slaaf is of vrije; daarbij is het niet van belang dat men man is of vrouw; want allen bent $\mathrm{u}$ één in Christus Jezus.' Een concept als 'mensenrechten' bijvoorbeeld bestaat dankzij het theologische framework dat de christelijke traditie levert. De radicale breuk met dit concept bij een beweging als het nazisme vloeide voort uit de afkeer die deze beweging had van het christendom. Wanneer het christendom niet bijna 2000 jaar lang onze cultuur had gedomineerd, zou de publieke opinie inzake mensenrechten, gelijkwaardigheid van man en vrouw, scheiding van kerk en staat, bestrijding van slavernij en rassendiscriminatie, afwijzing van seksuele onderdrukking (inclusief de \#Me Toobeweging) enzovoorts er vandaag de dag heel anders uitzien dan nu het geval is. Of we het nu willen en beseffen of niet, we zijn allemaal vissen die in christelijk water zwemmen.

Zoals te verwachten viel, krijgt Holland veel kritiek op deze stellingname. 
Zo is hem verweten dat hij als 'zelfbenoemd cultuurchristen' erg weinig aandacht zou besteden aan de vele schaduwkanten van het christendom en dat hij te gemakkelijk alles wat goed en deugdelijk is in de christelijke mal drukt (Kaj Brens). Dit oordeel acht ik niet terecht. Holland geeft zelf aan: 'I have sought, in writing this book, to be as objective as possible (...) to evaluate fairly both the achievements and the crimes of Christian civilisation' (518). Mijns inziens is hij hierin over het algemeen geslaagd. In het volgende duid ik enkele van deze licht- en schaduwzijden kort aan.

\section{Heilzame uitwerking}

De kruisdood was in de Romeinse tijd de meest ellendige en verachtelijke dood die maar denkbaar was. Met name slaven die op de ene of andere manier de fout waren ingegaan (of in elk geval door hun meesters negatief werden beoordeeld), werden aan kruisen opgehangen, waarbij hun lichamen te midden van afgrijselijke pijnen aan roofvogels ten prooi vielen en vervolgens in een massagraf werden gegooid. Op deze afschuwelijke manier hield de heersende klasse in de samenleving de vele slaven, dankzij wie ze een luxe leven kon leiden, met terreur onder de duim. Het is opmerkelijk dat we niet beschikken over gedetailleerde verslagen van deze breed toegepaste vorm van executie. Was het gewoon te schandelijk, te afgrijselijk voor woorden?

Des te opmerkelijker dat we beschikken over vier gedetailleerde beschrijvingen van het sterven van Jezus van Nazareth aan het kruis! Op geen enkele wijze hebben de evangelisten de in de ogen van Romeinen schandelijke en in de ogen van Joden vervloekte dood van hun Meester verdoezeld. Integendeel, ze plaatsten de Gekruisigde in het middelpunt van hun verkondiging en gingen zo ver te verklaren dat deze Jezus de HEERE der heerlijkheid, de enige, almachtige God in eigen Persoon was. Het moet absurd hebben geklonken in de oren van mensen in de Oudheid. Je tegenstanders kruisigen is het ultieme teken van absolute heerschappij over hen. Je laat als heerser je macht blijken door je overwonnen vijanden op deze manier op het diepst te vernederen (zoals dat bijvoorbeeld met vele Joden gebeurde bij de verwoesting van Jeruzalem in het jaar 70). Het is niet alleen ergerniswekkend en belachelijk, het lijkt totale gekte om nu te beweren dat uitgerekend een gekruisigde alle macht heeft in de hemel en op aarde. En toch was dat de kern van de christelijke boodschap die binnen enkele eeuwen de wereld veroverde.

Tom Holland is hier zelf diep verwonderd over. Terecht hoort hij in de boodschap van de Gekruisigde de hartenklop van het christelijk geloof: dat de allerhoogste God dichter bij het zwakke en ellendige staat dan bij de machtigen en rijken van deze wereld, en dat Christus zich nog altijd beweegt onder bedelaars en criminelen, zoals eens onder hoeren en tollenaars. God kiest het 
zwakke van deze wereld om het sterke te beschamen. Hij vestigt zijn heerschappij in het teken van het kruis.

Overal waar het christendom dicht bij het kruis gebleven is, zien we een warme golfstroom van echte menselijkheid door de geschiedenis heen. Hier passeren bekende en onbekende figuren uit de kerkgeschiedenis de revue. Een 'wolk van getuigen' komt in Hollands boek over het voetlicht. Daar zijn de martelaars tijdens de storm van vervolging rond het jaar 177 in Lyon en Vienne, zoals de slavin Blandina die onbevreesd de martelingen waaraan ze onderworpen werd doorstond, verzekerd als zij was van de hemelse kroon die haar wachtte. Zij en veel broeders en zusters met haar waren er diep van overtuigd dat Christus bij hen was in de kerkers en arena's en dat Hij met hen meeleed, net zo reëel als Hij eens aan het kruis had geleden. Tot op de dag van vandaag is er deze kerk onder het kruis die geduldig het grofste onrecht ondergaat in het voetspoor van de Meester.

Verder zijn er de velen die zich hebben beijverd in werken van barmhartigheid en voor de zaak van de gerechtigheid, waar mensen in de knel kwamen en mensenrechten met voeten werden getreden. Julianus Apostata ergerde zich eraan dat 'die goddeloze Galileeërs' (zoals hij de christenen beschimpte) niet alleen voor hun eigen armen zorgden, maar zich evenzeer ontfermden over niet-christenen in nood die op hun weg werden gebracht. De onbaatzuchtige inzet voor de armen is een rode draad in de kerkgeschiedenis. Zo stonden mannen als Basilius en Gregorius van Nyssa bekend om hun bewogenheid en gedrevenheid op dit punt. Basilius schrok er niet voor terug om als bisschop zelfs de melaatsen ondanks het besmettingsgevaar te groeten met een kus en hen te herbergen, omdat hij juist in de meest gebroken en ellendige mensen de Christus herkende. Zijn broer Gregorius ging nog een stap verder en bestreed de slavernij als een onvergefelijke zonde tegenover God die alle mensen in gelijkwaardigheid geschapen heeft. De zus van beide mannen, Macrina, ontfermde zich over te vondeling gelegde baby's in een tijd waarin pasgeboren kinderen maar al te vaak aan hun lot werden overgelaten. Martinus, in 371 verkozen als bisschop van Tours, koos er vrijwillig voor te leven als een bedelaar en daarmee de weelderigheid van zijn collegabisschoppen aan de kaak te stellen. Als jong soldaat had hij eens zijn eigen tuniek doormidden gesneden om de helft ervan in de koude van de winternacht aan een bedelaar te geven. Christus verscheen hem toen in een droom terwijl Hij die halve jas droeg en maakte hem duidelijk: 'Wat je deed voor de minste van je broeders, dat deed je voor Mij.' Dezelfde motivatie en bezieling zien we bij de Hongaarse prinses Elizabeth die na een leven van totale overgave en dienstvaardigheid onder meer in het door haar gestichte hospitaal in Marburg, in 1231 op 24-jarige leeftijd overleed. In dit spoor gingen Meropius 
Pontius Paulinus, de waldenzen, Franciscus van Assisi, Bartholomeus de las Casas die streed voor de bevrijding van de slaven, Johannes Calvijn die in Genève vele vluchtelingen opving, de quaker Benjamin Lay en zijn vrouw Sarah met hun taai verzet strijd tegen het instituut van de slavernij, Dietrich Bonhoeffer in zijn moedig getuigenis tegenover het nazisme, Martin Luther King in zijn boodschap van niet-discriminerende liefde, Nelson Mandela in zijn volhardende keus voor verzoening, enzovoorts.

\section{Beschamende schaduwkant}

Maar er is ook een heel ander verhaal te vertellen. Er zijn maar al te veel zwarte bladzijden in de geschiedenis van het christendom. Al te vaak hebben mensen die de naam hadden en zich er zelf op lieten voorstaan christenen te zijn, zich in feite metterdaad mijlenver verwijderd van het kruis en de Gekruisigde. Wat hebben mensen elkaar nota bene in naam van Christus en onder aanroeping van Gods naam gruwelijkheden aangedaan door vervolging van 'ketters', praktijken van inquisitie, burgeroorlogen. Wanneer Bonifatius bij Dokkum is vermoord, volgt er van de kant van de Frankische autoriteiten een hevige vergeldingsactie die de Friese wouden rood doet kleuren van het vergoten bloed. Karel de Grote dwingt mensen met het zwaard zich te laten dopen en laat, met een beroep op het door koning David gegeven voorbeeld, op één enkele dag 4500 (!) gevangenen onthoofden. Wanneer de kruisvaarders in 1099 Jeruzalem veroverd hebben op de Saracenen richten ze in de heilige stad een grote slachtpartij aan. In de Middeleeuwen worden de 'katharen' die voor duivelaanbidders werden gehouden op grote schaal geëxecuteerd, met name in het gebied rond Albi en Toulouse, dat beschouwd werd als een bijzonder schadelijk broeinest van als een kankergezwel uit te roeien ketterij. Het verhaal gaat dat bij de bestorming van Béziers sommigen bezorgd waren dat met de ketters ook katholieke gelovigen die zich in de stad konden bevinden, zouden worden gedood. Toen ze aan de pauselijke legaat vroegen wat te doen, zou deze hebben geantwoord: 'Dood ze allemaal, God kent toch wel degenen die de zijnen zijn.' De slachtpartijen gingen nog twintig jaar door totdat uiteindelijk in 1229 een in Parijs gesloten verdrag hier een eind aan maakte.

Het bloedvergieten in Gods naam bleef niet tot de Middeleeuwen beperkt. Jan Hus werd, ondanks de belofte van vrijgeleide door keizer Sigismund, in Konstanz na zijn veroordeling als ketter verbrand en zijn lichaam werd gedumpt in de Rijn. Vele brandstapels zouden worden aangericht in de eeuwen daarna, zeker toen de protestantse reformatie om zich heen greep en Rome alles op alles zette deze in de kiem te smoren. Denk bijvoorbeeld aan de verschrikkingen van de Bartholomeüsnacht, toen duizenden protestanten zijn vermoord, onder meer op de straten van Parijs en Lyon. Verwoestend 
was de Dertigjarige Oorlog tussen rooms - katholieke en protestantse vorsten, waarbij christelijke leerstellingen dienden als olie op het vuur van onderlinge haat en waarbij miljoenen mensen omkwamen. Verschrikkelijke dingen zijn er ook gebeurd in Mexico en in Amerika, waar de indianen in de naam van de christelijke 'beschaving' zijn uitgebuit, geplunderd en goeddeels uitgeroeid. In 1637 werd de stam van de Pequots door kolonisten uitgemoord. Vierhonderd mannen, vrouwen en kinderen werden dood achtergelaten te midden van hun brandende wigwams. Puriteinen die geschokt reageerden en protesteerden tegen dit geweld kregen als weerwoord dat God toch in het Oude Testament geweld had gesanctioneerd ter verdediging van het volk Israël. 'Soms verklaart de Schrift dat vrouwen en kinderen moeten omkomen met hun ouders. We hadden voldoende licht vanuit het Woord van God voor hetgeen we hebben gedaan.' Grover misbruik van Gods Naam is nauwelijks voorstelbaar. Maar het staat helaas niet alleen. Steeds weer zijn kwalijke zaken als rassendiscriminatie, onderdrukking van vrouwen of van minderheden, slavernij en uitbuiting van gekolonialiseerde landen met een beroep op bijbelteksten verdedigd.

Over zwarte bladzijden gesproken: de vijandschap van de christelijke kerk tegenover de Joden heeft er vele gevuld. Ook in dit boek lezen we er herhaaldelijk over. De houding van Origenes, mede gevoed vanuit zijn verzet tegen Marcion, betekende in de tijd van de vroege kerk eerder een uitzondering dan dat ze regel zou zijn. Hij toonde toewijding en eerbied voor de joodse erfenis die de christenen in het Oude Testament hebben ontvangen, leerde Hebreeuws van een Joodse leraar en erkende het Joodse volk als familie: de kleine zuster van de kerk ofwel de broer van de bruid. Maar in Afrika werden de Joden op bevel van keizer Heraclius gedwongen gedoopt. Ze werden door de eeuwen heen bij het gekerstende volk, maar ook in officiële kerkelijke uitspraken beschouwd als de getuigen van hun eigen perfidia en als levende bewijzen van Gods wrekende gerechtigheid. Hun wetten, gebruiken en leerstellingen werden als volkomen achterhaald beschouwd nu Jezus als de Messias immers gekomen was. Steeds weer vertelde men allerlei laster over hen die grif geloof vond. In 1255 werden achttien joden opgehangen op basis van valse beschuldigingen. Op het vierde Lateraanse concilie in 1215, onder de ketterjager paus Innocentius III, werd bepaald dat de joden evenals de moslims aparte kleding moesten dragen om onmiddellijk als joden herkenbaar te zijn. Christelijke kunstenaars begonnen hen karikaturaal af te beelden met dikke lippen, haakneuzen en gebochelde ruggen. Seksuele betrekkingen tussen joden en christenen werden in de ban gedaan. In 1290, respectievelijk 1306 werd hun verboden zich nog langer in Engeland en Frankrijk te bevinden. En zo ging het maar door tot het dieptepunt van de sjoah. 


\section{Toekomst van het christendom}

Hoe ziet Holland zelf de blijvende betekenis van het christendom nadat hij 'achievements' en 'crimes' honderden bladzijden lang tegen elkaar heeft afgewogen? Zijn evaluatie is positief en hij toont grote sympathie voor de kern van het christelijk geloof. Voor hem ligt er een rijk potentieel in de christelijke bronnen dat ook vandaag nog lang niet is uitgeput en verbindingen kan slaan tussen mensen die vanuit heel verschillende achtergronden zich inzetten voor vrede en gerechtigheid. Mooi is de referentie aan zijn peettante Deborah Gillingham (overleden in 2009), 'much loved, much missed', aan wie zijn boek is opgedragen. Deze vrouw die altijd vriendelijk en oprecht haar geloof praktisch handen en voeten gaf, liet de jonge Tom kennismaken met de verhalen uit de Bijbel. Op weg naar volwassenheid sijpelde het geloof bij Tom langzaam maar zeker weg. Hij beschrijft dit proces in een terugblik die ongetwijfeld bij velen in onze tijd herkenning oproept: 'Slowly, like a dimmer switch being turned down, I found my belief in God fading. The reaches of time seemed too icely immense for the life and death of a single human being two thousand years ago possibly to have had the cosmic significance claimed for it by Christianity' (520). Holland werd een cultuurchristen die zich rijk rekent met de nalatenschap van het christendom. We kunnen als gelovigen niet beter doen dan blijven bidden voor hem en voor de tallozen die denken zoals hij. Daarbij ook hen insluitend die zich resoluut van hun christelijke wortels willen bevrijden en de evaluatie van het christendom bij Holland veel te positief achten. Voor Holland bleef in elk geval zijn peettante onvergetelijk in haar warme getuigenis van doorleefd christelijk geloof en in haar hoopvol vredig sterven. En daarom weet hij: 'The Christian revolution was wrought above all at the knees of women' (519). Moeders en vaders, peetouders, ambtsdragers, onderwijzers en andere identificatiefiguren dragen ook in de $21^{\text {ste }}$ eeuw nog altijd de rijke traditie van het christelijk geloof over aan aankomende generaties, zodat deze onder de zegen van de Heilige Geest door hen wordt overgenomen en voortgezet - tot hun behoud en tot heil van de wereld. Als een erfenis van de Levende. 